\title{
A POTENTIAL LOW COST MEDIUM FOR CULTIVATION OF Dunaliella salina DCCBC15 IN VIETNAM
}

\author{
Tran Ngoc Duc ${ }^{1}$, Doan Thi Nhu Nguyen ${ }^{1}$, Ho Ky Quang Minh', \\ Nguyen Thi My Lan ${ }^{4}$, Sixto Portilla ${ }^{5}$, Hoang Tung $^{1}$, Duong Duc Tien ${ }^{2}$ \\ ${ }^{1}$ International University, VNU-Vietnam, Hochiminh city, *tnduc@ hcmiu.edu.vn \\ ${ }^{2}$ Institute of Microbiology and Environment, Ha Noi National University \\ ${ }^{3}$ Department of Environmental Science, Sai Gon University, Hochiminh city \\ ${ }^{4}$ University of Science, VNU-Vietnam, Hochiminh city \\ ${ }^{5}$ Center for Estuarine, Environmental and Coastal Oceans Monitoring, Dowling College, 150 Idle
}

Hour Blvd, Oakdale, New York 11769

\begin{abstract}
Dunaliella salina is a marine alga with high potential for beta-carotene (pro-vitamin A), up to more than $10 \%$ of cellular dry weight under appropriate stress conditions of limiting one of the following nutrients: nitrogen, phosphate, high light or high salt. Obtaining high biomass in low cost medium is the essential step of the two-phase culture system for beta-carotene production. For future development of beta-carotene production from Dunaliella in Vietnam, it is our first step to study a low cost medium using natural seawater enriched with industrial fertilizer N-P-K (30-15-10) commercially available in Vietnam. The primary results of biomass, cell density, chlorophyll a as well as growth rate are very promising to use this medium for mass culture of Dunaliella salina. The medium is recommended for growing other marine algae as well.
\end{abstract}

Keywords: Dunaliella salina, Beta-carotene, culture, growth, medium, pigment.

\section{INTRODUCTION}

Dunaliella belongs to the Chlorophytes $[8$, $11,12]$. There are about 26 saltwater species described for the genus of Dunaliella [5, 10, 11, 12]. Dunaliella salina TEODORESCO is a model organism and the type species of the genus, which vegetative cells are capable of turning orange under stress environments, such as high irradiance, high salinity, or low nutrient concentrations [3].

$D$. salina is one of the main sources for natural $\beta$-carotene, which is employed in the food, cosmetic and pharmaceutical industries and used as colorant, antioxidant and anticancer agent as well [3, 4].

Various artificial and natural seawater medium have been used for Dunaliella cultivation at lab and large scales $[1,2,7,8]$ However, looking for local resources to substitute for expensive proven methods is a practical and economical approach to cultivate Dunaliella in Vienam. In addition, Vietnam has a vast potential for Dunaliella beta-carotene production along coastal areas. This would contribute to regional economic and environmental stability of Asia and beyond. In the present study we investigate the growth of Dunaliella using local seawater enriched with industrial fertilizer (N-P-K) commercially available in Vietnam. This fertilizer also contains other additional micronutrients present in artificial medium and essential for Dunaliella growth [4]. The growth data showed a promising medium for higher biomass at low cost compared with artificial medium. The medium is recommended for growing other marine algae as well.

\section{MATERIALS AND METHODS}

\section{Dunaliella salina DCCBC15 and medium}

Dunaliella salina DCCBC15 was kindly provided by Dr. E.W. Polle, Department of Biology, Brooklyn College of CUNY Brooklyn, NY (USA). The alga was grown and maintained in the artificial $1.5 \mathrm{M} \mathrm{NaCl}$ medium according to Chitlaru E. and Pick U. (1989) [6]. Briefly, the medium contained $1.5 \mathrm{M} \mathrm{NaCl}$; $0.4 \mathrm{M}$ Tris$\mathrm{HCl}, 5 \mathrm{mM} \mathrm{KNO} 0_{3}, 5 \mathrm{mM} \mathrm{MgSO} 0_{4}, 0.3 \mathrm{mM}$ 
$\mathrm{CaCl}_{2}, 0.2 \mathrm{mM} \mathrm{KH}_{2} \mathrm{PO}_{4}, 1.5 \mu \mathrm{M} \mathrm{FeCl}_{3}$ in $6 \mu \mathrm{M}$ EDTA, $0.185 \mathrm{mM} \mathrm{H}_{3} \mathrm{BO}_{3}, 7 \mu \mathrm{M} \mathrm{MnCl}_{2}, 0.8 \mu \mathrm{M}$ $\mathrm{ZnCl}_{2}, 0.2 \mathrm{nM} \mathrm{CuCl}{ }_{2}, 0.2 \mu \mathrm{M} \mathrm{Na}_{2} \mathrm{MoO}_{4}, 20 \mathrm{nM}$ $\mathrm{CoCl}_{2}, 50 \mathrm{mM} \mathrm{NaHCO}$.

Six different $1.5 \mathrm{M} \mathrm{NaCl}$ media were devised for $D$. salina cultures including one artificial (MD1), and five enriched natural seawaters (MD2 to MD6) with detailed composition of each shown in table 1 . Components of NPK are listed as note below table 1. MD6 is enriched natural seawater with components according to García-González et al. (2003) [8] and Ana Prieto et al. (2011) [2] for open pilot culture. The NPK (code: Dau Trau 501) was bought from Binh Dien fertilizer company.

Table 1. Components of different media for growing Dunaliella salina

\begin{tabular}{|c|c|c|c|c|c|c|}
\hline Medium & MD1 & MD2 & MD3 & MD 4 & MD5 & MD6 \\
\hline & $\begin{array}{l}\text { Artifical }^{\mathrm{a})} \\
\text { (Tris-HCl) }^{\text {Trisl }}\end{array}$ & $\begin{array}{l}\text { Natural SW with } \\
\text { artificial } \\
\text { components } \\
\text { (Tris- } \mathrm{HCl} \text { ) }\end{array}$ & $\begin{array}{l}\text { Natural SW with } \\
\text { artificial } \\
\text { components } \\
\text { (no Tris-HCl) }\end{array}$ & $\begin{array}{l}\text { Natural SW } \\
\text { (no Tris- } \\
\text { HCl) }\end{array}$ & $\begin{array}{l}\begin{array}{l}\text { Natural SW } \\
\text { (no Tris- } \\
\mathrm{HCl} \text { ) }\end{array} \\
\end{array}$ & $\begin{array}{l}\text { Natural } \\
\text { SW } \\
\text { (no Tris- } \\
\mathrm{HCl} \text { ) }\end{array}$ \\
\hline $\mathrm{NPK}^{\mathrm{b})}$ & - & - & - & $0.1 \mathrm{~g} / 1$ & - & - \\
\hline MgS04 & - & - & - & $1.86 \mathrm{~g} / 1$ & $1.86 \mathrm{~g} / 1$ & - \\
\hline EDTA & - & - & - & $8.76 \mathrm{mg} / \mathrm{l}$ & $8.76 \mathrm{mg} / \mathrm{l}$ & - \\
\hline $\mathrm{FeCl} 3$ & - & - & - & $0.49 \mathrm{mg} / \mathrm{l}$ & $0.49 \mathrm{mg} / \mathrm{l}$ & - \\
\hline $\mathrm{MnCl} 2$ & - & - & - & $1.89 \mathrm{mg} / \mathrm{l}$ & $1.89 \mathrm{mg} / \mathrm{l}$ & - \\
\hline $\mathrm{NaHC03}$ & - & - & - & $50 \mathrm{mM}$ & $50 \mathrm{mM}$ & $2 \mathrm{mM}$ \\
\hline NaN03 & - & - & - & - & - & $\begin{array}{l}1.5 \\
\mathrm{mM}\end{array}$ \\
\hline $\mathrm{NaH} 2 \mathrm{P} 04$ & - & - & - & - & - & $\begin{array}{l}100 \\
\mu \mathrm{M}\end{array}$ \\
\hline $\mathrm{FeCl} 3.6 \mathrm{H} 20$ & - & - & - & - & - & $12 \mu \mathrm{M}$ \\
\hline
\end{tabular}

a). $1.5 \mathrm{M} \mathrm{NaCl} ; 0.4 \mathrm{M}$ Tris- $\mathrm{HCl}, 5 \mathrm{mM} \mathrm{KNO}_{3}, 5 \mathrm{mM} \mathrm{MgSO}_{4}, 0.3 \mathrm{mM} \mathrm{CaCl}_{2}, 0.2 \mathrm{mM} \mathrm{KH}_{2} \mathrm{PO}_{4}, 1.5 \mu \mathrm{M} \mathrm{FeCl}_{3}$ in $6 \mu \mathrm{M}$ EDTA, $0.185 \mathrm{mM} \mathrm{H}_{3} \mathrm{BO}_{3}, 7 \mu \mathrm{M} \mathrm{MnCl}_{2}, 0.8 \mu \mathrm{M} \mathrm{ZnCl}_{2}, 0.2 \mathrm{nM} \mathrm{CuCl} 2,0.2 \mu \mathrm{M} \mathrm{Na}_{2} \mathrm{Mo}_{4}, 20 \mathrm{nM}$ $\mathrm{CoCl}_{2}, 50 \mathrm{mM} \mathrm{NaHCO}$; b). N-P-K (30-15-10): 30\% N, 15\% P205, 10\% K20, 0.05\% Mg, 0.05\% Ca, 0.01\% B, $0.05 \% \mathrm{Zn}, 0.05 \% \mathrm{Cu}, 0.05 \% \mathrm{Fe}, 0.025 \% \mathrm{Mn}, 0.005 \% \mathrm{Mo}$.

Seawater with salinity about $0.5 \mathrm{M}$ collected from Long Hai beach, Vung Tau province, was filtered to remove sand and other small particles. All media were autoclaved after adding chemicals according to table 1 .

\section{Experimental design}

The experiment had six treatments as mentioned above. One liter of algal culture was grown in 2 liter flask with 3 replicates for each treatment. The cultures were maintained at room temperature of $25^{\circ} \mathrm{C}$, and light intensity of 50 $\mu$ moles $\mathrm{m}^{-2} \mathrm{~s}^{-1}$. The experiment lasted for 24 days.

\section{Chlorophyll analysis}

Pigment extraction was carried out according to Dipak S. Psal and S. S. Lele (2005)
[7]. Briefly $5 \mathrm{ml}$ of Dunaliella salina was centrifuged at $8,000 \mathrm{rpm}$ for $20 \mathrm{~min}$. The pellet was washed with distilled water and suspended in an acetone $80 \%$ solution, then vortexed well and centrifuged to extract pigments. Optical density of the extract was taken by spectrophotometric method, using UV-VIS spectrophotometer (Thermal scientific, Model: G10SUV-Vis, SN: 2L9P271002) to determine chlorophyll a concentrations of the samples. Chlorophyll a $(\mathrm{Ca})$ was calculated according to Lichtentaler and Wellburn formulas (1985) [9]: $\mathrm{Ca}(\mu \mathrm{g} / \mathrm{ml})=11.75(\mathrm{~A} 662)-2.350(\mathrm{~A} 645)$.

\section{Growth analysis}

Cell count was performed using a 
Haemacytometer and calculated as: Cells $/ \mathrm{ml}=$ total cells $\times 10^{4} \times$ dilution factor.

For biomass, briefly culture was filtered through $47 \mathrm{~mm}$ glass fiber filters with $0.7 \mu \mathrm{m}$ nominal pore size. The filter was washed with ammonium formiate $(0.5 \mathrm{M})$, dried at $103^{\circ} \mathrm{C}$ for 6 hours for dry weight. The dry weight was further burned in furnace at $550{ }^{\circ} \mathrm{C}$ to obtain ash weight. Biomass is calculated as dry weight $\left(103^{\circ} \mathrm{C}\right)$ - ash weight $\left(550^{\circ} \mathrm{C}\right)$.

Growth rate (GR) was calculated in the first 14 days of culture as: GR $(\mathrm{g} / \mathrm{l} / \mathrm{d})=(\operatorname{bio}(\mathrm{t})-$ $\operatorname{bio}(0)) /\left(t-t_{0}\right)$, where $\operatorname{bio}(0)$ is biomass at time $(0)$ and bio $(\mathrm{t})$ is the biomass at time $(\mathrm{t})$.

\section{Statistical analysis}

Data was tested by one-way ANOVA analysis using SPSS software. All significant levels were set at $\mathrm{p}<0.05$.

\section{RESULTS AND DISCUSSION}

Results of the different media with respect to cell density, biomass and chlorophyll-a are shown in figure 1 . The medium (MD4) enriched with industrial fertilizer N-P-K (30-15-10) facilitated best performance overall. The differences of cell density, biomass and chlorophyll a were significant among different media $(\mathrm{p}<0.05)$.
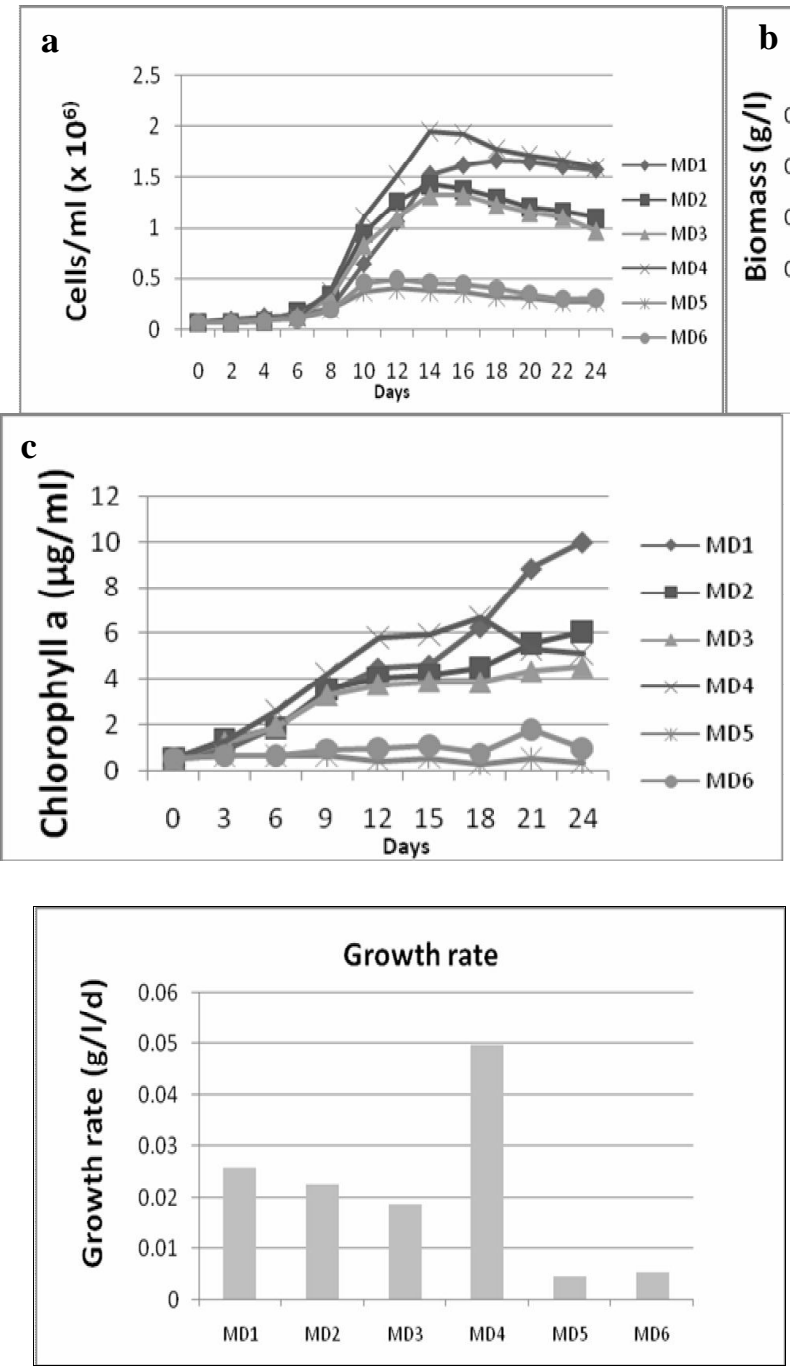

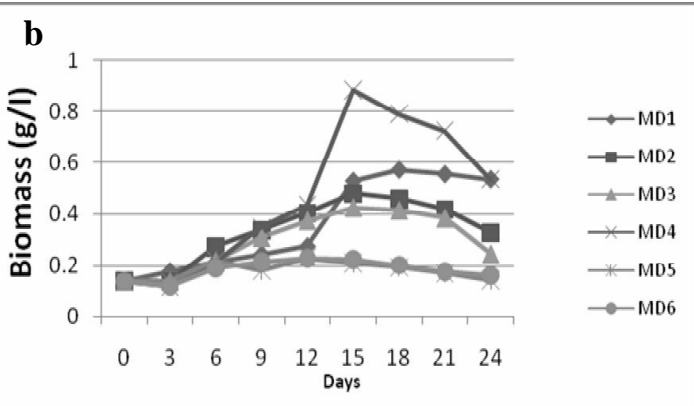

Figure 1. Cell density (a), biomass (b) and chlorophyll a (c) of Dunaliella salina grown in six different media (MD1 to MD6)

Figure 2. Growth rate of Dunaliella salina grown in six different media (MD) 
Figure 2 compares overall growth rate data for the 6 experimental media. MD4 and MD1 show the most effective media, followed by MD2 and MD3, then MD5 and MD6. Overall, MD4 (table 1) containing $0.1 \mathrm{~g}$ NPK showed the most effective growth for Dunaliella. The difference was significant $(\mathrm{p}<0.05)$

\section{DISCUSSION}

The abundance of natural seawater in Vietnam provides a great opportunity to develop large scale cultivation of Dunaliella for highvalue carotenoid production. Identifying a low cost, effective local medium is an important first step. Although Dunaliella adapted to all media and started to grow after 3 days, it performed best in the MD4 medium of seawater enriched with locally available industrial fertilizer. This was determined through consensus of biomass, cell density and chlorophyll-a data (figure 1), as cultures reached stationary phase after 2 weeks. The success of MD4 is underscored by the absence of Tris- $\mathrm{HCl}$, a high cost component comprising over $90 \%$ of media MD1 and MD2. As figure 1 clearly shows a decline in biomass after 15 days, it is recommended that nutrients be supplemented to cultures approximately every two weeks to sustain continued growth. This new medium is currently used in our lab for most of marine strains, and their growths are very effective (Tran et al., unpublished data). The effectiveness of this new medium could be due to other minerals and micronutrients (undefined yet) present in the natural seawater. In addition, higher concentration of phosphate, $\mathrm{Cu}$ and the presence of three hormones ( $\alpha \mathrm{NAA}, \beta \mathrm{NOA}$, GA3) in N-P-K (compared with components in artificial medium: MD1) (table 1) could also have better effects on Dunaliella growth. Carotene and antioxidant capacity of Dunaliella salina grown in these medium will be investigated. In addition, further study on the effects of these specific components, other limiting nutrients, light intensity, and salt concentration on productivity of Dunaliella growth is on progress in our lab to improve the effectiveness of this new medium better.

Acknowledgement: The researchers are grateful to Vietnam Faundation for Science and
Technology Development (NAFOSTED) under grant number 106.16-2011.31 and the funding of HCM National University to carry out this research (Funding number: B2012-28-02/HDDHQT-QLKH). The authors are also grateful to Dr. Jeurgen Polle at Department of Biology, Brooklyn college for providing Dunaliella salina DCCBC15 for the study and his valuable advices. The authors would like to thank anonymous reviewers of this manuscript for correction and improvement.

\section{REFERENCE}

1. Ali Hosseini Tafreshi, Mansour Shariati, 2006. Pilot culture of three strains of Dunaliella salina for beta-carotene production in open pond in the central region of Iran. World Journal of Microbiology \& Biotechnology, 22: 1003-1006.

2. Ana P., Cañavate J. P., García-González M., 2011. Assessment of carotenoid production by Dunaliella salina in different culture systems and operation regimes. Journal of Biotechnology, 151: 180-185.

3. Ben-Amotz A., Katz A., Avron M., 1982. Accumulation of $\beta$-carotene in halotolerant algae: purification and characterization of $\beta$ carotene rich globules from Dunaliella bardawil (Chlorophyceace). J. Phycol., 18: 529-537.

4. Borowitzka M. A., Borowitzka L. J., 1988. Dunaliella. In Microalgal Biotechnology. Cambridge University Press, Cambridge, UK, pp. 27-58.

5. Borowitzka M. A., Siva C. J., 2007. The taxonomy of the genus Dunaliella (Chlorophyta, Dunaliellales) with emphasis on the marine and halophilic species. J. Appl. Phycol., 19: 567-590.

6. Chitlaru E., Pick U., 1989. Selection and Characterization of Dunaliella salina Mutants Defective in Haloadaptation. Plant Physiol., 91: 788-794.

7. Dipak S. Psal, S. S. Lele, 2005. Carotenoid production from microalga, Dunaliella salina. Indian Journal of Biotechnology, 4: 476-483. 
8. García-González M., Moreno J., Cañavate J. P., Anguis V., Prieto A., Manzano C., Florencio F. J. and Guerrero M. G., 2003. Conditions for open-air outdoor culture of Dunaliella salina in southern Spain. Journal of Applied Phycology, 15: 177-184.

9. Lichtenthaler H. K., Wellburn A. R., 1985. Determination of total carotenoids and chlorophylls A and B of leaf in different solvents. Biol. Soc. Trans., 11: 591-592.

10. Massjuk N. P., 1972. On phylogeny and taxonomy of the genus Dunaliella Teod.
Ukr. Bot. Zh. 29:744-750.

11. Polle J. E. W, Tran D., Ben-Amotz A., 2009. Chapter 1: History, Distribution, and Habitats of Algae of the Genus Dunaliella TEODORESCO (Chlorophyceae). Book in press: The Alga Dunaliella: Biodiversity, Physiology, Genomics \& Biotechnology'.

12. Tawfiq S. Abu-Rezq, Suad Al-Hooti, Dangly A. Jacob, 2010. Optimum culture conditions required for the locally isolated Dunaliella salina. J. Algal Biomass Utln. 1(2): 12-19.

\title{
MÔI TRƯờNG TIỀM NĂNG VỚI GIÁ THÀNH THẤP CHO NUÔI TRỒNG TẢO BIỂN Dunaliella salina DCCBC15 Ở VIẸT NAM
}

\author{
Trần Ngọc Đức ${ }^{1 *}$, Đoàn Thị Như Nguyện ${ }^{1}$, Hồ Kỳ Quang Minh ${ }^{3}$, \\ Nguyễn Thị Mỹ Lan ${ }^{4}$, Sixto Portilla ${ }^{5}$, Hoàng Tùng ${ }^{1}$, Dương Đức Tiến ${ }^{2}$ \\ ${ }^{1}$ Đại học Quốc tế, ĐHQG Tp. Hồ Chí Minh \\ ${ }^{2}$ Viện vi sinh và môi trường, ĐHQG Hà Nội \\ ${ }^{3}$ Khoa môi trường, ĐHSG Tp. Hồ Chí Minh \\ ${ }^{4}$ Đai học Khoa học tự nhiên, ĐHQG Tp. Hồ Chí Minh \\ ${ }^{5}$ Trung tâm Nghiên cứu cửa sông, biển và môi trường, Đại học Dowling, Hoa Kỳ
}

\section{TÓM TẮT}

Dunaliella salina là một loài tảo biển, có khả năng tổng hợp beta-carotene cao (tiền vitamin $\mathrm{A}$ ), lên tới hơn $10 \%$ trọng lượng khô của tế bào trong những điều kiện ức chế của một số yếu tố dinh dưỡng sau: thiếu nitơ, thiếu phospho, lượng ánh sáng và nồng độ muối cao. Đạt được hàm lượng sinh khối cao ở môi trường giá thành thấp này là một bước rất cần thiết của hệ thống nuôi hai giai đoạn cho việc sản xuất beta-carotene. Để cho sự phát triển sản xuất beta-carotene từ Dunaliella ở Việt Nam trong tương lai, bước đầu tiên của chúng tôi nghiên cứu môi trường rẻ tiền sử dụng nước biển tự nhiên bổ sung với phân bón N-P-K (30-15-10) hiện có ở Việt Nam. Những kết quả bước đầu cho thấy hàm lượng sinh khối, mật độ tế bào, diệp lục tố a cũng như tốc độ tăng trưởng có triển vọng khi sử dụng môi trường này cho việc nuôi cấy Dunaliella ở quy mô công nghiệp. Môi trường này cũng có thể được áp dụng nuôi cấy cho những loài tảo biển khác.

Tù khóa: Dunaliella salina, Beta-caroten, môi trường, nuôi cấy, sắc tố, sự tăng trưởng.

Ngày nhận bài: 24-1-2013 